\title{
ENVIRONMENTAL FACTORS: DOMINANT MOTIVATION OF THE BONGAN COMMUNITY TO SUPPORT THE DEVELOPMENT OF TOURIST VILLAGE
}

\author{
I Made Darma Oka ${ }^{1}$, Putu Widya Darmayanti ${ }^{2}$ \\ Jurusan Pariwisata, Politeknik Negeri Bali ${ }^{1}$ \\ Akademi Pariwisata Denpasar, $\mathrm{Bali}^{2}$ \\ madedarmaoka@pnb.ac.id
}

\begin{abstract}
This article discusses the factors that motivate the Bongan's community to support the development of tourist village. The research used qualitative and quantitative data collected by distributing questionnaires to and conducting an in-depth interview with those who are knowledgeable of the tourism development at the Bongan village. The samples included 100 respondents determined using the proportional random sampling technique. The data were analyzed using the confirmatory factor analysis technique to confirm the factors that motivate the local community to support the development of tourist village. The research shows that the environmental, social, community participation, and cultural factors have significantly contributed to support the development of tourist village. The environmental factor is the most dominant one followed by the social, community participation, and cultural factors. This mean that the environmental factor is the main reason why the local community supports the development of tourist village at the Bongan village.
\end{abstract}

Keywords: Motivation; community; development of tourist village

\section{INTRODUCTION}

Bongan village is a tourist village in Tabanan Regency. The determination of the village to be a tourist village by the Tabanan Regional Government through the decree No. 180/445/03 / HK \& HAM 2018. The aims to develop the potentials of the village to empower local communities optimally. To realize this goal the Bongan community has built a management called the Tourism Awareness Group (Pokdarwis). The duties of Pokdarwis to manage and prepare everything to support the smooth development of tourism at Bongan village. So the village become a tourist villages that ready to compete when developing quality tourism.

The development of quality tourism in Bali can be applied because the community is depend on the tourism sector (Utama \& Rai, 2013). The development of quality tourism has implemented the principles of sustainable tourism development, such as: ecotourism, agro-tourism, spiritual tourism, rural tourism, community-based tourism, which has begun to be implemented to maximize the development of tourist village.

The changes of tourist motivation in make a holiday addressed through by the implementation of community-based tourism (CBT) principles. The 
implementation of CBT must be adjusted to the needs of the local community for the sustainability of the development of tourist village at Bongan, by adopting the four principles of CBT, namely: the development of tourist village giving the economic benefits to the local community; the development of tourist villages focused on community empowerment; the development of tourist village increase the social and cultural conservation; and the development of tourist villages must preserve nature and the environment (Chambers, 1997). Furthermore Alavalapati \& Adamowicz (2000); Gelbman \& Timothy (2011); Nunkoo et al. (2012) states that when developing tourist destinations, it is necessary to build balance between economic benefits and the environment in a real way and empower local communities maximally to increase awareness and high responsibility in tourism development. Referring the expert's opinion, in developing tourist destinations should to implement of CBT principles.

Developing CBT at Bongan village requires genuine community participation by, from, and for the community. The emergence of the process participation in the context of community empowerment based on two perspectives, namely: the involvement of local communities in planning until the implementation of the program and transformational participation as a goal to change the marginal conditions become to empower. Hopefully that the community will benefit optimally from the development of tourist villages.

The participation of Bongan community in the development of tourist village is an implementation of the CBT model that emphasizes an important element of community involvement in planning and managing tourism potential in the village. Putra (2015) mentions CBT is a form of tourism which the local communities have substantial control and involvement in development and management; and the proportion of benefits remains largely in the hands of the community. This is in line with research by Ishii (2012); Agarwal (2012); Suasapha \& Paturusi (2015) which states that the development of tourist destinations can increase in the economy benefit of the local community. However, it is different from Scott (2012) research which states that the developing tourist destinations necessary to sets social benefits higher than economic benefits so that tourist villages can be sustainable.

The motivation of the community to participate in and support the development of tourism at Bongan Village is the result of internal and external processes involving every individual, causing them to follow the steps taken to support the development of tourism enthusiastically and persistently. The local community are aware that the development of tourism at their village benefits them. The internal factors which support the development of tourism can be in the forms of personality, attitude, experience and education or different expectations which can lead them to their future. One of the external factors is the environment where the local people live (Winardi, 2002). It is further stated that the factors which can contribute to motivation are: (1) the personal needs, (2) the goals and perception of someone or a group of people; (3) how such needs and goals can be realized. Thus, the motivation of the people living at Bongan Village to support tourism has inspired them to participate. Suansri (2003) said that the community participation in working at tourist village are influenced by social, economic, community participation, cultural, and environmental factors. How strong or weak the local community motivation to participate in the activities done to support the 
development of tourism depends on what advantages they can feel from the development of tourism

Based on what was described above, it can be stated that there are several internal and external factors which have contributed to the local community motivation to support the development of tourism at the village. This current study discusses on the factors motivating the local community to support the development of tourism at Bongan Village from the social, economic, cultural, and environmental perspectives. Therefore, the theory of motivation and the concept of the community-based tourism (CBT) were used to analyze the local people motivation to support the development of tourism at Bongan Village

\section{METHODOLOGY}

The number of samples used in the current study was determined using the opinion proposed by Hair et al. (2006), in which it is stated that the number of the samples feasibly investigated through the factor analysis should be at least five times the total variables. The sixteen variables were determined in the current study taken from each factors (social, economic, community participation, cultural, and environmental), and to make it more representative the respondents used totaled 100. The samples were taken using the proportional random sampling technique (Sugiyono, 2014). The Confirmatory Factor Analysis was used to analyze the factors motivating the local community to support the tourism development at Bongan Village. The local community's motivation to support the tourism development was made from variable X1 to X16. The four common factors, namely the environment factor, the social factor, the cultural factor, and the community participation factor. The factors and variables contributing to the local community's motivation to support the development of tourist village at Bongan could be identified through the factor analysis.

\section{RESULTS AND DISCUSSION}

Initially the parameters tested in analysis of the factors that motivated the Bongan community in the development of tourist villages amounted to 20 parameters. But after being tested there are 16 parameters that are designed into the factors. Then the rotation is carried out to clarify each parameter to enter into each formed the factor. Factor analysis results obtained that $\mathrm{KMO}>0,600$ which is equal to 0.810 with a value of Bartlett's test is 795.438 with a significance level at 0.000 so it is reasonable to include all parameters in factor analysis individually.

Then the data were analyzed using the SPSS 17.0 application. The results show that the parameters as forming community motivation factors to support the development of tourist villages are divided into four factors (Table 1), namely: 1) environmental factors consisting of: tourism businesses, the influence of western culture, the development of tourist villages, and environmental cleanliness; 2) social factors, included: social status, pride, community cooperation and community participation; 3) community participation factors included: employment opportunities, community support, local culture, community power, community rights and community involvement; and 4) cultural factors included: community awareness and culture environmental sustainability. 
Table 1

Total Variance Explained Bongan Tourist Village

\begin{tabular}{|c|c|c|c|c|}
\hline \multicolumn{5}{|c|}{ Initial Eigenvalues } \\
\hline No & Factor & Total & Variance & Cumulative \\
\hline 1 & Environmental & 5.352 & 33.448 & 33.448 \\
\hline 2 & Social & 2.653 & 16.580 & 50.028 \\
\hline 3 & Society participation & 1.308 & 8.175 & 58.203 \\
\hline & Cultural & 1.087 & 6.794 & 64.997 \\
\hline
\end{tabular}

Source: Research results

Table 1 shows that the number of factors formed in the factor analysis was 4 factors. With an eigenvalue $>1$, it can show that these factors are forming community motivation to development Bongan tourist village. The column shows the four factors that have an eigenvalue $>1$, namely environmental factors, have total initial eigenvalues value are 5.352 with the variation of $33.448 \%$, social factor are 2.653 with the variation of $16.580 \%$, community participation factor are 1.308 with the variation of $8.175 \%$ and cultural factors with the total initial eigenvalues are 1.087 with the variations of $6.794 \%$. It can be said that the most dominant factor contributing to community motivation in supporting the development of tourist village is an environmental factor with a total eigenvalues contribution of 5.352. follows:

The description of each parameter forming each factor, can be described as

\section{Environmental Factors}

The results of environmental factors analyze indicate that the parameters classified into this factor amounted four parameters. 1)The parameters of the benefits derived from local community sourced from tourism businesses, 2) The influence of western culture that can strengthen the culture of local communities such as cultural preservation, 3) The development of tourist villages which will be able to foster public awareness in environmental preservation, and 4) Local communities that increasingly care about the importance of environmental cleanliness. All four parameters have a matrix component value of $>0,600$ meaning that the four parameters in environmental factors have a significant influence to community's motivation to support the development of tourist villages.

Table 2. Components Matrix of Environmental Factors

\begin{tabular}{lll}
\hline No & \multicolumn{1}{c}{ Parameters } & Score \\
\hline 1 & $\begin{array}{l}\text { The profits derived from local people sourced from tourism } \\
\text { businesses }\end{array}$ & 0.941 \\
2 & $\begin{array}{l}\text { The influence of western culture that can strengthen the culture of } \\
\text { local communities such as cultural preservation }\end{array}$ & 0.864 \\
3 & $\begin{array}{l}\text { The development of tourist village which will be able to foster } \\
\text { public awareness in environmental preservation }\end{array}$ & 0.641 \\
\hline & $\begin{array}{l}\text { The community increasingly that care about the importance of } \\
\text { environmental cleanliness }\end{array}$ & 0.887 \\
\hline
\end{tabular}

Source: Research results

From the four parameters, the most dominant parameter influencing 
community motivation to support the development of tourist villages is the local community profit derived from tourism businesses parameter. It is realized that benefiting from the development of tourist villages, make able to foster their awareness in maintaining sustainable village environment. This indicates that the existence of the environment determines the sustainability from the conditions of the village order. This means that the village of Bongan is designated as a tourist village must have a good cultural environment, facilities, access, and nature so able create harmony between the people as a provider of tourism services with tourists as the users.

The environment also become source of community life, meaning the community gets feedback from businesses managed in the tourist village environment. The environment is a form reflection of people's lives so that the village has a program of environmental clean activities. This is supported by the opinion of I Wayan Nadi (Secretary of Bongan Village) in an interview on 29/3/19 which stated that there are awareness/movement of the village community in protecting and preserving the environment by conducting village clean activities for the sustainability of the tourist village.

\section{Social Factors}

The results of the analysis social factors indicate that there are three parameters included in social factors, namely: the development of the village as a tourist village able to improve the social status of the community, the local community feels proud to the development of tourist village, and the local community is able to work together in organizing tourism activities in the village. These three parameters have a matrix component $>0,600$ (Table 3 ). With the value of the rotated component matrix determined, this means that the three parameters have a significant influence on community's motivation to support the development of tourism villages.

Table 3. Components Matrix of Social Factors

\begin{tabular}{lll}
\hline No & \multicolumn{1}{c}{ Para meter } & Score \\
\hline 1 & $\begin{array}{l}\text { The development of the village as a tourist village can improve } \\
\text { social status }\end{array}$ & 0.688 \\
2 & $\begin{array}{l}\text { Local community feel proud in the development of the tourist } \\
\text { village }\end{array}$ & 0.762 \\
3 & $\begin{array}{l}\text { Local community are able to work together in organizing tourism } \\
\text { activities in the village }\end{array}$ & 0.800 \\
\hline
\end{tabular}

Source: Research results

These parameters are included in social factors because each parameter discusses the social identity that owned by the community in the development of tourist village. The most dominant parameter influencing in this factors is the local community able to cooperate with each other in organizing tourism activities in the village. This evidence is supported by the opinion of the community which states that $34 \%$ of them stated strongly agree, $38 \%$ stated agreed, $15 \%$ were doubtful, and less agreed only $13 \%$. This means that the community understands the conditions around them, where the community appreciate each other so the community feels that it's important to the development of tourist village such as a meeting activity to discuss planning of tourism activities. Besides that, the villagers cooperate with 
each other in coordinating activities related to tourism through cultural parade activities. This shows the pride of the village community when they together felt success in the development of tourist village. This is in line with the findings of Oka et al. (2015); Winia, et al (2019) which states that social factors significantly influence labor participation in tourism industry.

\section{Community Participation Factors}

The results of analysis community participation factors indicate that there are six parameters included in this factor, namely: designation of the village as a tourism village provides new employment opportunities for local communities, local communities are able to play an active role to support the tourism activities in village, tourism activities in the tourist villages accordance with local culture, increasing the power of local communities as managers in tourism activities at village, the development of rural tourism continues to guarantee the rights of local communities in the management of natural resources owned, and the local community is actively involved in tourism activities at village start the planning, implementation, monitoring and evaluation stages (Table 4).

Table 4. Components Matrix of Society Participation Factors

\begin{tabular}{lll}
\hline No & \multicolumn{1}{c}{ Parameters } & Score \\
\hline 1 & $\begin{array}{l}\text { The designation of a tourist village provides new } \\
\text { employment opportunities for local communities }\end{array}$ & 0.752 \\
2 & $\begin{array}{l}\text { Local communities able to play an active role in } \\
\text { supporting tourism activities in the village }\end{array}$ & 0.668 \\
3 & $\begin{array}{l}\text { Tourism activities in the tourist village in accordance with } \\
\text { local culture }\end{array}$ & 0.653 \\
4 & $\begin{array}{l}\text { Increasing the power of local communities in managing } \\
\text { tourism activities at the village }\end{array}$ & 0.671 \\
5 & $\begin{array}{l}\text { The development of tourist villages guarantees the rights } \\
\text { of local communities in managing their natural resources }\end{array}$ & 0.771 \\
6 & $\begin{array}{l}\text { Local communities are actively involved in tourism } \\
\text { activities at the village starting from the planning, } \\
\text { implementation, monitoring and evaluation stages }\end{array}$ & 0.753 \\
\hline
\end{tabular}

Source: Research results

Based on the results of factor analysis shows that the six parameters included in the community participation factor significantly influence the motivation of the community to support the development of tourist village because the matrix component value $>0,600$. These parameters were included in the community participation factor because each parameter discusses the design of community participation in supporting the development of tourist villages. The parameter that gives the most dominant influence is the parameter of developing tourist villages while guaranteeing the rights of local communities in managing their natural resources. This evidence is supported by data on the frequency of community opinion, which states that $23 \%$ of them stated strongly agree, $53 \%$ agreed, $14 \%$ were doubtful, and 10 stated less agree. This means that the local community plays a role as a leader in the management of the tourist village.

The fact shows that the designation of village as a tourist village is able to provide new employment opportunities for local people by recruiting the 
community as a manager of tourist attractions, joining the Chirping Bali community, food stall owners and villa employees. In the management of tourist villages, local people are able to be involved in supporting tourism activities at village. The community feels happy to be involved in activities (mesuryak traditions, cultural parades) in an effort to preserve and preserve culture. In addition, the community felt that the designation of Bongan village as a tourist village was able to provide new employment opportunities for local people. This evidence is supported by data on the frequency of society opinion which states that $23 \%$ agree strongly, 53\% agree, 14\% doubt, and only 10\% disagree. This finding in line with Sutrisna (2011); Sadia \& Oka (2012); Oka (2017); Winia et al. (2019); Oka \& Sumawidari (2018); Winia et al. (2019) which stated that the tourism sector has been created employment opportunities for the community through the opening of various types of businesses related to tourism that can be exploited by workers.

\section{Cultural Factors}

Based on the results of the factor analysis shows that there are two parameters included in the cultural factors, namely: local community realize that through cultural conservation the village is attracting tourists to visit and the existence of tourist village is applying the principle of cultural sustainability in the development of tourism activities.

Table 5. Components Matrix of Cultural Factors

\begin{tabular}{lll}
\hline No & \multicolumn{1}{c}{ Para meter } & Score \\
\hline 1 & $\begin{array}{l}\text { Local people realize that through cultural conservation is attracting } \\
\text { tourists to visit }\end{array}$ & 0.768 \\
2 & $\begin{array}{l}\text { The existence of tourist village is applying the principle of cultural } \\
\text { sustainability in development of tourism activities }\end{array}$ & 0.756 \\
\hline
\end{tabular}

Source: Research results

The results of the factor analysis show that the two parameters included in the cultural factor significantly influence to motivate of the community to develop the Bongan tourist village. These parameters were included in cultural factors because each parameter discusses the influence of cultural conservation in the development of tourist village. The parameter that gives a stronger influence is the parameter of the local community realizing that through cultural conservation is attracting tourists to visit the tourist village.

This evidence show that two parameters significantly influences community motivation is culture has a major influence in the development of tourist village. The fact shows that the culture of the Bongan village is preserved until this day so that it can be enjoyed by the future generations. The existence of the Bedha Temple with the Kebo Iwa site which has become an icon of tourist village until now. The existence of Kebo Iwa site is attracting for tourists to visit. This shown that the village of Bongan has applied the principle of environmental sustainability. This is in line with the findings of Oka et al. (2018); Winia et al. (2019) which states that the development of tourist destinations must have component of tourism attractions both natural and cultural as the main support in the development of the sustainable tourism. 


\section{CONCLUSSION}

The factors that motivate the community to support the developing of tourist villages at Bongan Tabanan are four factors, namely: social, cultural, community participation and environmental factors. After being tested statistically the results showed that environmental factors were the dominant motivation of Bongan community to support the development at tourist village, then social factors, community participation factors, and cultural factors. This means that the Bongan community supports the development of tourist village, which has the main goal of maintaining environmental sustainability. Hopefully the government will play a greater role in the development of the Bongan tourist village, especially in providing guidance and direction that relevant with community-based tourism models to be implemented according to its potential. Community awareness need to maintain and preserve the natural and cultural environment to develop the tourist villages in the future.

\section{ACKNOWLEDGMENTS}

We are saying thankful to all informant and respondents for providing me information and kind support throughout the research work. And we are also saying thankful to the God.

\section{REFERENCES}

Agarwal, S. (2012). Resort economy and direct economic linkages. Annals of Tourism Research, 39(3), 1470-1494.

Alavalapati, J. R. R., \& Adamowicz, W. L. (2000). Tourism impact modeling for resource extraction regions. Annals of Tourism Research, 27(1), 188-202.

Chambers, E. (1997). Tourism and culture: an applied perspective. SUNY Press.

Gelbman, A., \& Timothy, D. J. (2011). Border complexity, tourism and international exclaves: A case study. Annals of Tourism Research, 38(1), $110-131$.

Hair, J. F., Black, W. C., Babin, B. J., Anderson, \& Tatham, R.E., Ronald, L. (2006). Multivariate Data Analysis. Pearson Prentice Hall.

Ishii, K. (2012). The impact of ethnic tourism on hill tribes in Thailand. Annals of Tourism Research, 39(1), 290-310.

Nunkoo, R., Ramkissoon, H., \& Gursoy, D. (2012). Public trust in tourism institutions. Annals of Tourism Research, 39(3), 1538-1564.

Oka, I. M. D. (2017). The Multiplier Effect Of Balinese Labor Working On Cruise Ship. Journal of Business on Hospitality and Tourism, 2(1), 107. https://doi.org/10.22334/jbhost.v2i1.46

Oka, I. M. D., Antara, M., \& Mudana, I. G. (2015). Socio-cultural implication of balinese women working on cruise ship. Journal of Cultural Studies, 8(3), 96-101.

Oka, I. M. D., \& Sumawidari, I. A. K. (2018). The Factors That Motivate Balinese Women Working On Cruise Ships. International Journal of Applied Sciences in Tourism and Events, 2(2), 125-134.

Oka, I. M. D., Winia, I. N., \& Sadia, I. K. (2018). Pemetaan Potensi Pariwisata Dalam Mendukung Pengembangan Pariwisata Di Desa Serangan. Bhakti Persada Jurnal Aplikasi IPTEKS, 4(1), 47-54. 
Putra, I. N. D. (2015). Pariwisata berbasis masyarakat model Bali. Buku Arti.

Sadia, I. K., \& Oka, I. M. D. (2012). Motivasi Tenaga Kerja Bali Bekerja di Mediterranean Shipping Company (MSC). Jurnal Sosial Humaniora, 2(3), 221-236.

Scott, J. (2012). Tourism, civil society and peace in Cyprus. Annals of Tourism Research, 39(4), 2114-2132.

Suansri, P. (2003). Community based tourism handbook. Responsible Ecological Social Tour-REST.

Suasapha, A. ., \& Paturusi, S. A. (2015). Pariwisata Berbasis Masyarakat Dalam Pengelolaan Pantai Kedonganan: Pariwisata Berbasis Masyarakat Model Bali. Universitas Udayana.

Sugiyono. (2014). Metode Penelitian Manajemen. Alfabeta.

Sutrisna, E. (2011). Problematika Perempuan Bekerja di Sektor Pariwisata (Studi Kasus Perhotelan). Jurnal Aplikasi Bisnis, 1(2), 97-102.

Utama, I., \& Rai, G. B. (2013). Strategi menuju pariwisata Bali yang berkualitas. Jurnal Kajian Bali, 3(02), 69-90.

Winardi, J. (2002). Motivasi dan pemotivasian dalam manajemen. Raja Grafindo Persada.

Winia, I. N., Oka, I. M. D., \& Pugra, I. W. (2019). The Implementation of the Community-based Tourism at Tista Tourist Village. International Conference On Applied Science and Technology 2019-Social Sciences Track (ICASTSS 2019). 